\title{
IN VITRO ANTIBACTERIAL ACTIVITY OF SELECTED UNDERUTILIZED PLANTS AND CYTOTOXIC PROPERTY OF TERMINALIA CATAPPA
}

\author{
SOMARATHNA THIKSHANI ${ }^{1,3,6}$, PREMAKUMARA GAS ${ }^{2}$, AKBARSHA A. MOHAMMAD ${ }^{3,}$ KADALMANI \\ BALAMUTHU ${ }^{4,5,6}$, WEERAKKODY SEVWANDIKA NIMSHA6*
}

\begin{abstract}
1Department of Food Science and Technology, Faculty of Graduate Studies, University of Sri Jayewardenepura, Nugegoda, Sri Lanka, ${ }^{2}$ Industrial Technology Institutes, 396, Bauddhaloka Mw, Colombo, Sri Lanka, ${ }^{3}$ Mahatma Gandhi-Doerenkamp Center, Bharathidasan University, Tiruchirappalli 620024, India, ${ }^{4}$ Department of Animal Science, School of Life Sciences, Bharathidasan University, Tiruchirappalli, India, ${ }^{5}$ UGC National Centre for Alternatives to Animal Experiments, Bharathidasan University, Tiruchirappalli, India, ${ }^{6 *}$ Department of Agricultural and Plantation Engineering, Faculty of Engineering Technology, The Open University of Sri Lanka, Nawala, Sri Lanka Email: nweer@ou.ac.lk
\end{abstract}

Received: 05 Aug 2017 Revised and Accepted: 02 Nov 2017

\section{ABSTRACT}

Objective: This study aimed at determining the antibacterial activity of the underutilized plants of Sri Lanka, "Kottamba" (Terminalia catappa), "Purpurata" (Alpinia purpurata) and "Harankaha" (Curcuma zedoaria), against food-borne pathogens. Chemical composition and in vitro cytotxicity of the most active antibacterial plant extract(s) were examined.

Methods: Crude rhizome extracts were obtained for all plants whereas in respect of T. catappa, the red pericarp of the fruit was used. The antibacterial activity was determined using the agar disc diffusion and broth dilution assays. Total phenol content, Gas Chromatograph-Mass Spectrometry analysis and cytotoxicity assay were conducted only with the plant which showed the most effective antibacterial activity.

Results: T. catappa extract showed significantly (p<0.05) high DIZ $(19.6 \pm 0.47 \mathrm{~mm})$ against $S$. aureus 113 . A. purpurata showed DIZ $(16.3 \pm 0.94$, $15.0 \pm 1.00,14.3 \pm 0.57 \mathrm{~mm}$ ) against L. monocytogenes V7 (1/2a), S. aureus 25925 and S. aureus MSSASS 25D. The MIC of T. catappa ethanol extract was $10 \mathrm{mg} / \mathrm{ml}$, while MBC was $80 \mathrm{mg} / \mathrm{ml}$ for $S$. aureus 113 . The phenolic content of $T$. catappa ethanol extract was $81.54 \pm 1.28 \mathrm{mg}$ GAE/g dry sample and the major compound (31.86 \%) was 2, 5-Furandione, 3 methyl. The No-Observed Adverse Effect Concentration (NOAEC) of this extract for COS7 cells was $100 \mu \mathrm{g} / \mathrm{ml}$ whereas for $3 \mathrm{~T} 3$ it was $300 \mu \mathrm{g} / \mathrm{ml}$. This indicates that the extract is cytotoxic only at a very high concentration, suggesting that at lower concentrations the extract could be used as a food preservative.

Conclusion: The results indicate that T. catappa has potential antibacterial activity as a safe bio-preservative.

Keywords: Terminalia catappa, Antibacterial activity, GC-MS, NOAEC, Cytotoxicity

(C) 2017 The Authors. Published by Innovare Academic Sciences Pvt Ltd. This is an open access article under the CC BY license (http://creativecommons.org/licenses/by/4.0/) DOI: http://dx.doi.org/10.22159/ijpps.2017v9i12.21835

\section{INTRODUCTION}

Food-borne diseases are a global issue with significant impact on human health. The widespread use of antibiotics promotes antibacterial resistance which in turn increases the burden of health care. In the present scenario, the emergence of multiple drug resistance to human pathogenic organisms has necessitated a search for new antimicrobial substances, synthetic as well as natural. However, consumers are hesitant to use synthetic drugs in view of the side effects [1]. It is evident that over time consumers look for natural antimicrobials to prevent food-borne infectious diseases. Particularly, the antimicrobial activity of plant oils and extracts has been the basis for most of the preservatives, pharmaceuticals, alternative medicines and natural therapies [2].

About $80 \%$ of the world population relies on herbal medicines as primary source of health care [3]. But the potential of higher plants as source of new drugs is still largely unexplored. Among the estimated 250,000-500,000 plant species, only a small percentage has been investigated from phytochemical perspectives, and the fraction submitted to biological or pharmacological screening is even smaller [4]. Therefore, several more plants should be investigated to better understand their medicinal properties, safety and efficiency.

Among the underutilized plants of Sri Lanka, Terminalia catappa, Alpinia purpurata and Curcuma zedoaria are used in the preparation of traditional medicines since ancient times [5]. Antibacterial activity has been reported in the fruit [6], leaf [7], bark [8] and root [9-10] of T. catappa, mostly the green variety. Leaf [11], fruit [12], and root [13] of $A$. purpurata have been investigated for antibacterial activity against $S$. aureus, E. coli, and Salmonella sp. However, to the best of our knowledge, there has been no report of antimicrobial activity of the $A$. purpurata varieties grown in Sri Lanka. Curcuma zedoaria Rosc has been reported for antimicrobial [14], antifungal [15] and other activities. Nevertheless, no antibacterial testing of $C$. zedoaria has been carried out against opportunistic pathogens such as L. monocytogenes.

Safety aspects of any natural chemical compound need to be investigated since otherwise it may lead to deleterious effects in man and animals. On the other hand, repeated administration of doses can produce unwanted side effects in tissues and organs. Therefore, toxicity testing is required for the most potential antibacterial active plant extracts. However, there are no pharmacological safety studies on T. catappa. Therefore, the objective of this study has been to find the antibacterial property of T. catappa, A. purpurata and C. zedoaria against selected food-borne pathogens. Further, total phenol content and cytotoxic property of the most active antibacterial extract were also determined. The novelty of the study lies in finding plants with antimicrobial property, with cytotoxicity being induced only at concentrations that are not toxic, so as to ensure efficacy as food preservative but safe for human/animal consumption, and to decipher the potentially active phyto-compound (s).

\section{MATERIALS AND METHODS}

\section{Plant materials}

T. catappa and $A$. purpurata were collected from the premises of the Open University of Sri Lanka Nawala. Curcuma zedoaria was 
collected from the medicinal garden of the Nature Secret Pvt Ltd, Millewa, Horana, Colombo, Sri Lanka. Voucher specimens were placed in the herbarium of the Department of Agricultural Plantation Engineering, The Open University of Sri Lanka.

\section{Chemicals and reagents}

n-Hexane, Trypton Soya Broth (TSB), Trypton Soya Agar (TSA), Mueller-Hinton Agar (MHA), Violet Red Bile Glucose Agar (VRBG), Xylose Lysine Desoxycholate Agar (XLD), Dulbecco's modified Eagle's Medium (DMEM), Tween 20, Dimethyl sulphoxide (DMSO), Folin Ciocalteu Reagent, Sodium Carbonate and Gallic Acid were obtained from Sigma-Aldrich Chemical Co., (St. Louis, MO, USA). Phosphate-Buffered Saline (PBS) and 3-(4, 5-Dimethylthiazol-2-yl)2, 5-Diphenyltetrazolium Bromide (MTT) were purchased from HiMedia Laboratories (Mumbai, India). Fetal Bovine Serum (FBS), Trypsine-EDTA, Penicillin and Streptomycin were obtained from Invitrogen (USA). All other chemicals and reagents were of analytical grade.

\section{Preparation of extracts}

The rhizomes of A. purpurata and C. zedoaria, and red pericarp of $T$. catappa were used for extraction. Fresh rhizomes and fruits, respectively, were cleaned by washing in running tap water. The rhizomes were peeled off and cleaned. The rhizomes and fruit pericarp were sliced and oven-dried at $40{ }^{\circ} \mathrm{C}$ for $24 \mathrm{~h}$. The slices were then powdered to fine particles using a grinder (National Super Blender, Taiwan, Model MX-TIIOPN) for $5 \mathrm{~min}$ at adequate intervals. The powders were stored at $20^{\circ} \mathrm{C}$ until use.

$\mathrm{N}$-Hexane and ethanol were used as solvents for extraction. The extract was prepared by adding $10 \mathrm{~g}$ of each powder to $100 \mathrm{ml}$ of $\mathrm{n}$ hexane or ethanol and agitated for $24 \mathrm{~h}$ at $30^{\circ} \mathrm{C}$ in a rotary shaker (Stuart® Orbital Shaker SSL1, UK). The mixture was filtered using Whatman No 1 filter paper under vacuum and the filtrate was evaporated under vacuum at $40{ }^{\circ} \mathrm{C}$ using a rotary evaporator (KIA RV 5, Switzerland). The concentrated extract was filter-sterilized through a $0.45 \mu \mathrm{m}$ filter units (Millex ${ }^{\circledR} \mathrm{HA}$, Germany). The filtrate was subjected to $\mathrm{N}_{2}$ flux under heat $\left(40^{\circ} \mathrm{C}\right)$ for $3 \mathrm{~h}$ until a hexanefree extract was obtained. Finally, the concentrated extract was redissolved in DMSO to make a $0.5 \mathrm{~g} / \mathrm{ml}$ stock solution and stored at 4 ${ }^{\circ} \mathrm{C}$ until use.

\section{Test micro-organisms and cell culture}

The antibacterial activity of the extract was determined by using food-borne bacteria. S. aureus 113, S. aureus MSSA SS 25D, S. aureus MSSA SS 21D, Listeria monocytogenes Scott A (4b), L. monocytogenes V7 (1/2a), and L. monocytogenes EDG were obtained from University of Queensland, Brisbane, Australia. S. aureus ATCC 29213, S. aureus ATCC 49476, S. aureus ATCC 25925, L. monocytogenes ATCC 7644, Escherichia coli (E. coli) ATCC 1858 and Salmonella typhimurium (S. typhimurium) ATCC 14028 were obtained from American Type Culture Collection (Manassas, USA). The bacterial strains were confirmed using Gram staining method. Baird Parker Agar with egg yolk tellurite emulsion was used for the identification of $S$. aureus strains. E. coli and S. typhimurium were identified using VRBG agar medium and XLD agar medium, respectively. All bacterial strains were stored in $80 \%$ glycerol at $80^{\circ} \mathrm{C}$ as frozen stock cultures. Working cultures were grown and maintained in Trypton Soy Agar (TSA).

Monkey kidney (COS7) and mouse fibroblast (3T3) cells were obtained from National Center for Cell Science (NCCS), Pune, India. The cells were maintained in Dulbecco's modified Eagle's medium (DMEM) supplemented with $10 \%$ FBS, and with $20 \mathrm{ml}$ each of penicillin and streptomycin as antibiotics, and $1.2 \mathrm{~g} \mathrm{Na}_{2} \mathrm{HCO}_{3}$ was added to it, in a humidified atmosphere of $5 \% \mathrm{CO}_{2}$ and $95 \%$ air, in a $\mathrm{CO}_{2}$ incubator (Thermo Scientific, USA).

\section{Disk diffusion assay}

Antibacterial activities of the extracts were evaluated using slightly modified disk diffusion method described previously by Barry [16]. A single colony of bacteria was grown in 2 ml Trypton Soy Broth (TSB) at $37^{\circ} \mathrm{C}$ for $18 \mathrm{~h}$. The content was centrifuged (Centurion Scientific Ltd, UK) at $10000 \mathrm{x}$ g for $10 \mathrm{~min}$ to obtain the bacterial pellet. The supernatant was removed and the bacterial pellet was re-suspended in $1 \mathrm{ml}$ sterile $0.85 \% \mathrm{NaCl}$. The preparation was pipetted to $9 \mathrm{ml}$ of sterile $0.85 \% \mathrm{NaCl}$ solution to obtain $5 \times 10^{5} \mathrm{CFU} / \mathrm{ml}$. Then, $100 \mu \mathrm{l}$ of dilute bacterial suspension was spread on Mueller Hinton Agar (MHA) plates. An aliquot $(10 \mu \mathrm{l})$ of the plant extract was pipetted on to a 5.5 $\mathrm{mm}$ diameter sterile paper disc (Whatman No1) on the agar surface. Streptomycin $(100 \mu \mathrm{g} / \mathrm{ml})$ served as the positive control while DMSOcontaining disc served as the negative control. The plates were then inverted and incubated at $37{ }^{\circ} \mathrm{C}$ for $18 \mathrm{~h}$. Microbial inhibition was determined, in triplicate, by measuring the Diameter of inhibition around each disc and recorded as DIZ in millimeter.

\section{Broth dilution assay}

The Minimum Inhibitory Concentration (MIC) and the Minimum Bactericidal Concentration (MBC), were determined against $S$. aureus 113 and S. aureus ATCC 29213 with some modifications of the method described by Hennekinne et al. [17] with the plant showing the strongest antibacterial activity for which quantitative two-fold serial dilutions of extracts were performed. Thus, two-fold serial dilution of T. catappa ethanol extract was made with Mueller Hinton Broth (MHB). After $160 \mu \mathrm{l}$ of T. catappa extract was added to the first tube containing $2 \mathrm{ml}$ of $\mathrm{MHB}$, the tube was kept in a $50{ }^{\circ} \mathrm{C}$ water bath for $5 \mathrm{~min}$ for solublizing the content, and two-fold serial dilution was made up to the seventh tube. Since solubility of the extract was low, one drop of Tween $20(4.6 \mathrm{mg})$ was added to solublize the extract. An aliquot of $10 \mu \mathrm{l}\left(5 \times 10^{5} \mathrm{CFU} / \mathrm{ml}\right)$ of the test organism was added to each test tube.

Streptomycin $(100 \mu \mathrm{g} / \mathrm{ml})$, MHB containing the microorganism and media only were used as positive-, negative-and media control. The tubes were incubated, without shaking, at $37^{\circ} \mathrm{C}$. The tubes were visually examined for the lowest concentration of extract which showed clear solution after $24 \mathrm{~h}$ and $48 \mathrm{~h}$. The concentration in the lowest serial dilution of the extract at which growth did not occur on broth was recorded as MIC. All the tubes that did not show any turbidity were used to take $100 \mu \mathrm{l}$ of each suspension and spread on the surface of TSA plates. Then the plates were incubated at $37^{\circ} \mathrm{C}$, for $24 \mathrm{~h}$ and $48 \mathrm{~h}$. The lowest extract concentration at which no bacterial growth was observed on TSA plate was taken as MBC. All assays were performed independently three times each in triplicates. The same procedure was followed for A purpurata ethanol extract in quantification of MIC and MBC for $L$. monocytogenes Scott A and E. coli as these bacteria responded with a strong antibacterial activity in the disk diffusion assay.

\section{Total phenol content}

The total phenol content of the extract of T. catappa was determined using Folin-Ciocalteu colorimetric method adopted from Shan et al. [18] with some modifications. An aliquot of $100 \mu \mathrm{l}$ of an appropriate dilution of the extract was oxidized for 4 min with $0.5 \mathrm{ml}$ of FolinCiocalteu reagent. The reaction was neutralized with $0.5 \mathrm{ml}$ of sodium carbonate $(75 \mathrm{~g} / \mathrm{l})$. After two hour incubation at $26^{\circ} \mathrm{C}$ the absorbance of the color was measured at $760 \mathrm{~nm}$ in a spectrometer (6300, Jenway, UK). Gallic acid was used as the standard to plot a curve where concentrations of $0,1,5,10,2575,100,150 \mathrm{mg} / \mathrm{ml}$ were prepared using deionized (DI) water. A standard curve was plotted using the absorbance obtained using the procedure described previously. Absorbance of the extract was determined using a standard curve of Gallic acid and the results are given in milligram of Gallic Acid Equivalent (GAE) per gram of dry sample. All tests were performed independently three times each in triplicates.

\section{Chemical composition of the plant}

T. catappa crude ethanol extract was analyzed by GC-MS using an Agilent make model 6890 gas chromatograph with a HP-5 MS column and an Agilent 5973 mass selective detector. The temperature was first held at $50{ }^{\circ} \mathrm{C}$ for $2 \mathrm{~min}$ and then raised gradually to $250{ }^{\circ} \mathrm{C}$ at $10{ }^{\circ} \mathrm{C} / \mathrm{min}$ interval and held at $250{ }^{\circ} \mathrm{C}$ for 8 min. The carrier gas was helium at a flow rate of $0.9 \mathrm{ml} / \mathrm{min}$ and injection volume was $1 \mu \mathrm{l}$. The identities of the main component peaks were confirmed by comparison of their retention time with those of reference compounds using Wiley W9N08 data base library. The percentage of each compound was calculated as the ratio of the peak area to the total chromatographic area. 


\section{MTT assay for assessment of cell viability}

Cell viability, which would reveal the cytotoxic property of the plant extract, was evaluated using the MTT colorimetric assay with some modifications [19]. Cells were seeded in 96-well plates at $5 \mathrm{x}$ $10^{3} \mathrm{cells} /$ well and incubated for $24 \mathrm{~h}$ at $37^{\circ} \mathrm{C}$. The cells were treated with the extract at increasing concentrations within $0-1000 \mu \mathrm{g} / \mathrm{ml}$ for $24 \mathrm{~h}$, at $37^{\circ} \mathrm{C}$. Dilution of stock solutions was made in the culture medium yielding final extract concentrations in the DMSO concentration of $0.1 \%$. This concentration of DMSO did not affect the cell viability [20]. DMSO was used as the solvent control. Control cells were incubated in culture medium only. Experiments with each extract concentration were conducted in triplicates on the same batch of cells. After $24 \mathrm{~h}$ incubation, $20 \mathrm{ml}$ of MTT solution $(5 \mathrm{mg} / \mathrm{ml}$ in PBS) was added to each well, and incubated for $3 \mathrm{~h}$ at $37^{\circ} \mathrm{C}$. The medium was then removed and $100 \mathrm{ml}$ of DMSO was added to each well to dissolve the purple formazan product. The absorbance was measured at $570 \mathrm{~nm}$ using a 96-well plate reader (Bio-Rad, Hercules, CA, USA). Data were collected for triplicates independently three times and used to calculate the respective means and standard deviations. The percentage inhibition was calculated from this data using the following formula, and the $\mathrm{IC}_{50}$ was calculated. The $\mathrm{IC}_{50}$ is defined as concentration of the test substance at which cell viability is decreased to $50 \%$.

$$
\text { Percentage of cell Inhibition }=\frac{\text { Mean OD (control) }- \text { Mean OD (treatment) }}{\text { Mean OD (control) }} \times 100
$$

\section{Morphological assessment of cell death using AO/EB fluorescent assay}

The morphological characteristics of cells indicating apoptosis and necrosis were assessed by AO/EB staining [21]. The cells were cultured in 6-well plates and treated with $\mathrm{IC}_{50}$ and no toxicity concentrations $(130 \mu \mathrm{g} / \mathrm{ml}, 300 \mu \mathrm{g} / \mathrm{ml}$, respectively) of T. catappa extracts for $24 \mathrm{~h}$ against COS7 and 3T3 cells, respectively. The treated and untreated cells were centrifuged (3000 rpm for $4 \mathrm{~min}$ ) and incubated with AO and EB solutions (1 part of $100 \mathrm{mg} / \mathrm{ml}$ each of $\mathrm{AO}$ and $\mathrm{EB}$ in PBS) and observed in a fluorescent microscope (Carl Zeiss, Jena, Germany) using a UV filter (450-490 nm).

Three hundred cells per sample were counted, in duplicate, and scored as viable or dead, and if dead whether by apoptosis or necrosis as judged from nuclear morphology and cytoplasmic organization. Then, percentages of apoptotic and necrotic cells were calculated. The appropriate morphological features were photographed.

\section{Assessment of nuclear features using hoechst 33528 staining}

The nuclear morphological features of the cells were assessed using Hoechst 33528 staining [22]. The cells were cultured in 6-well plates and treated with $T$. catappa extracts alone, at their respective $\mathrm{IC}_{50}$ concentrations and no toxicity concentration, for $24 \mathrm{~h}$. After incubation, the treated and control cells were harvested and stained with Hoechst $33258(1 \mathrm{mg} / \mathrm{ml}$ in PBS) for $5 \mathrm{~min}$ at room temperature. A drop of cell suspension was placed on a glass slide, and covered with a cover slip. At random 300 cells, in triplicate, were observed at $x 400$ in the fluorescent microscope fitted with a 377-355 nm filter. Then, the percentage of cells reflecting pathological changes was calculated.

\section{Statistical analysis}

The triplicate data were subjected to analysis of variance of the general linear model using SPSS statistical software, at $5 \%$ significance level. Means were compared using Turkey's simultaneous test set at $P<0.05$.

\section{RESULTS}

\section{Antibacterial activities of the extracts}

The mean DIZ of A. purpurata, T. catappa and C. zedoaria, measured in disk diffusion assay, are shown in the table 1 . A significant $(\mathrm{p}<0.05)$ variation was found in antibacterial activity between $\mathrm{n}$-hexane and ethanol extracts for each of the plants tested. The ethanol extract of $T$. catappa showed significantly $(\mathrm{p}<0.05)$ higher overall DIZ, $19.6 \pm 0.47$ and $19.3 \pm 0.47 \mathrm{~mm}$, against $S$. aureus 113 and S. aureus ATCC 29213, respectively, but not hexane extract. Further, T. catappa ethanol extract showed significantly $(\mathrm{p}<0.05)$ larger DIZ against all $S$. aureus strains tested except $S$. aureus MSSA SS 21D. A. purpurata extract produced a significantly $(\mathrm{p}<0.05)$ larger DIZ with $L$. monocytogenes V7 $(1 / 2 a)$ irrespective of the solvent but not so when tested against $S$. aureus 113 . However, no significant result in DIZ was obtained with hexane extract of $A$. purpurata against S. aureus 25925 and S. aureus ATCC 49476. A. purpurata ethanol extract produced significant $(\mathrm{p}<0.05)$ inhibition $(9.3 \pm 0.57 \mathrm{~mm})$ against $E$. coli. Similarly, C. zedoaria produced significant $(\mathrm{p}<0.05)$ inhibition $(8.6 \pm 0.57 \mathrm{~mm})$ of $S$. typhimrium ATCC 14028 . The disk diffusion assay for $C$. zedoaria hexane extract showed higher inhibition of $11.6 \pm 0.57$ and $12.0 \pm 0.00 \mathrm{~mm}$ against $S$. aureus 113 and $S$ aureus MSSA SS 21D, respectively. No significant ( $>0.05)$ difference in DIZ between A. purpurata ethanol, and T. catappa and C. zedoaria hexane extracts was observed against $E$. coli and $S$. typhimurium. These values were always smaller than or equal to the DIZ obtained with the Grampositive bacteria.

Table 1: Diameter of inhibition zone ( $\mathrm{mm})$ of the plant extracts

\begin{tabular}{|c|c|c|c|c|c|c|}
\hline \multirow[t]{2}{*}{ Micro-organism } & \multicolumn{2}{|l|}{ A. purpurata } & \multicolumn{2}{|l|}{ T. catappa } & \multicolumn{2}{|l|}{ C. zedoaria } \\
\hline & Hexane & Ethanol & Hexane & Ethanol & Hexane & Ethanol \\
\hline SA 25925 & $15.0 \pm 1.00^{\text {cdef }}$ & $11.3 \pm 0.57^{\mathrm{ijk}}$ & $6.0 \pm 0.00^{w}$ & $17.6 \pm 0.47 \mathrm{bc}$ & $10.0 \pm 0.00^{\mathrm{mn}}$ & $9.0 \pm 0.00^{\mathrm{pq}}$ \\
\hline$S A$ MSSA SS 25D & $14.3 \pm 0.57$ defg & $9.3 \pm 0.57^{\circ p}$ & $6.0 \pm 0.00^{w}$ & $19.0 \pm 0.81^{\mathrm{ab}}$ & $9.0 \pm 0.00 \mathrm{pq}$ & $7.0 \pm 0.00^{\text {uv }}$ \\
\hline SA ATCC 29213 & $14.3 \pm 0.57$ defg & $10.6 \pm 0.57 \mathrm{klm}$ & $6.0 \pm 0.00^{w}$ & $19.3 \pm 0.47^{a}$ & $12.0 \pm 0.00 \mathrm{ghi}$ & $7.0 \pm 0.00^{\text {uv }}$ \\
\hline SA MSSA SS 21D & $14.0 \pm 0.00^{\mathrm{efgh}}$ & $10.3 \pm 0.57 \mathrm{~lm}$ & $9.6 \pm 0.00^{\mathrm{n} \circ \mathrm{p}}$ & $11.6 \pm 0.57^{\mathrm{hij}}$ & $11.3 \pm 0.57^{\mathrm{ijk}}$ & $9.0 \pm 0.00 \mathrm{pq}$ \\
\hline SA ATCC 49476 & $15.0 \pm 1.00^{\text {cdef }}$ & $11.3 \pm 0.57^{\mathrm{ijk}}$ & $6.0 \pm 0.00^{w}$ & $18.6 \pm 0.94^{\mathrm{ab}}$ & $9.3 \pm 0.57^{\circ p}$ & $10.0 \pm 0.00^{\mathrm{mn}}$ \\
\hline$S A 113$ & $13.0 \pm 1.73^{\mathrm{fgh}}$ & $12.3 \pm 0.57 \mathrm{ghi}$ & $6.0 \pm 0.00^{w}$ & $19.6 \pm 0.47^{a}$ & $11.6 \pm 0.57^{\text {hij }}$ & $10.0 \pm 0.00^{\mathrm{mn}}$ \\
\hline$L M S \operatorname{cott} \mathrm{A}$ & $14.0 \pm 0.64^{\mathrm{efgh}}$ & $13.6 \pm 0.57^{\mathrm{fgh}}$ & $6.0 \pm 0.00^{w}$ & $12.6 \pm 0.57^{\mathrm{ghi}}$ & $7.3 \pm 0.57^{\mathrm{tu}}$ & $8.6 \pm 0.57 \mathrm{qr}$ \\
\hline$L M$ V7 (1/2a) & $16.3 \pm 0.94 \mathrm{bcd}$ & $15.6 \pm 0.57$ cde & $6.0 \pm 0.00^{w}$ & $13.3 \pm 0.57^{\mathrm{fgh}}$ & $7.0 \pm 0.00^{\mathrm{uv}}$ & $6.0 \pm 0.00^{\mathrm{w}}$ \\
\hline$L M$ EGD & $14.3 \pm 0.57^{\text {defg }}$ & $11.3 \pm 0.57^{\mathrm{ijk}}$ & $6.6 \pm 0.57 \mathrm{vw}$ & $11.0 \pm 0.00^{\mathrm{jkl}}$ & $10.3 \pm 0.57^{\mathrm{lm}}$ & $8.0 \pm 0.00^{\mathrm{rs}}$ \\
\hline LM ATCC7644 & $13.0 \pm 1.73^{\mathrm{fgh}}$ & $11.0 \pm 0.00^{\mathrm{jkl}}$ & $6.0 \pm 0.00^{w}$ & $12.6 \pm 0.57 \mathrm{ghi}$ & $10.0 \pm 0.00^{\mathrm{mn}}$ & $9.0 \pm 0.00 \mathrm{pq}$ \\
\hline E. coli & $7.6 \pm 2.88^{\mathrm{st}}$ & $9.3 \pm 0.57^{\circ \mathrm{p}}$ & $6.6 \pm 0.57 \mathrm{vw}$ & $6.0 \pm 0.00^{w}$ & $6.0 \pm 0.00^{w}$ & $6.0 \pm 0.00^{w}$ \\
\hline S. typhimrium & $7.6 \pm 2.88^{\mathrm{st}}$ & $6.6 \pm 0.00^{v w}$ & $6.0 \pm 0.00^{w}$ & $6.0 \pm 0.00^{w}$ & $6.0 \pm 0.00^{w}$ & $8.6 \pm 0.57 \mathrm{qr}$ \\
\hline Streptomycin & 17.0 & 18.0 & 18.0 & 5.5 & 18.0 & 18.0 \\
\hline DMSO & 6.0 & 6.0 & 6.0 & 6.0 & 6.0 & 6.0 \\
\hline
\end{tabular}

$\mathrm{SA}=$ S. aureus, $\mathrm{LM}=$ L. monocytogenes. ${ }^{*}$ Means inhibition $(\mathrm{mm}) \pm \mathrm{S}$. $\mathrm{D}$ of three replicates with different lowercase letters is significantly $(\mathrm{P}<0.05)$ different.

\section{Broth dilution assay}

The MIC and MBC values obtained at 24 and $48 \mathrm{~h}$ using broth dilution assay for the ethanol extract of $T$. catappa and $A$. purpurata are presented in table 2 . The MIC value of $T$. catappa extract against S. aureus 113 strain was $10 \mathrm{mg} / \mathrm{ml}$ at $24 \mathrm{~h}$ whereas $\mathrm{MBC}$ was found to be $80 \mathrm{mg} / \mathrm{ml}$ irrespective of the strain, and the value did not change at $48 \mathrm{~h}$. The MIC for A. purpurata hexane extract was $5 \mathrm{mg} / \mathrm{ml}$ and $10 \mathrm{mg} / \mathrm{ml}$ against L. monocytogenes $V 7$ and E. coli, respectively. 
Table 2: The MIC and MBC values of the plant extracts against food-borne pathogens

\begin{tabular}{|c|c|c|c|c|c|}
\hline \multirow[t]{3}{*}{ Plant } & \multirow[t]{3}{*}{ Name of the organism } & \multicolumn{4}{|c|}{ Concentration $(\mathrm{mg} / \mathrm{ml})$ of extract } \\
\hline & & \multicolumn{2}{|c|}{ MIC } & \multicolumn{2}{|l|}{ MBC } \\
\hline & & $24 \mathrm{~h}$ & $48 \mathrm{~h}$ & $24 \mathrm{~h}$ & $48 \mathrm{~h}$ \\
\hline T. catappa & S. aureus 113 & 10 & 10 & 80 & 80 \\
\hline (ethanol) & S. aureus ATCC29213 & 10 & 10 & 80 & 80 \\
\hline A. purpurata & L. monocytogenes V7 (1/2a) & 5 & 5 & 20 & 20 \\
\hline (n-hexane) & E. coli & 10 & 10 & $>20$ & $>20$ \\
\hline
\end{tabular}

MIC of T. catappa indicates activity within the range of the concentrations tested $(0.625-80 \mathrm{mg} / \mathrm{ml})$, and $\mathrm{A}$. purpurata within the range of the concentration tested $(1.25-20 \mathrm{mg} / \mathrm{ml})$.

\section{Total phenol content (TPC)}

The antibacterial activity of plant extracts might be attributed to the presence of bioactive plant compounds. TPC of T. catappa was found to be $81.54 \pm 1.28 \mathrm{mg} / \mathrm{GAE} / \mathrm{g}$ in ethanol extract.

\section{GC-MS analysis}

The GC-MS data are presented in fig. 1. The compounds identified in the spectrum are presented in table 3 . with only chemical compounds greater than $1 \%$ are shown. The T. catappa ethanol extract contained 13 compounds at $>1 \%$, accounting for $97.9 \%$ of the total composition of the extract. The major chemical compound, the one obtained at the highest concentration in ethanol extract, was 2, 5-furandione, 3-methyl as identified from Wiley W9N08 data base library (31.86\%). The second most abundant compound was 2 -fural carboxaldehyde $(29.33 \%)$. The other compounds such as furane $(15.66 \%)$ and cyclophentanol (4.51\%) were also identified in the ethanol extract.

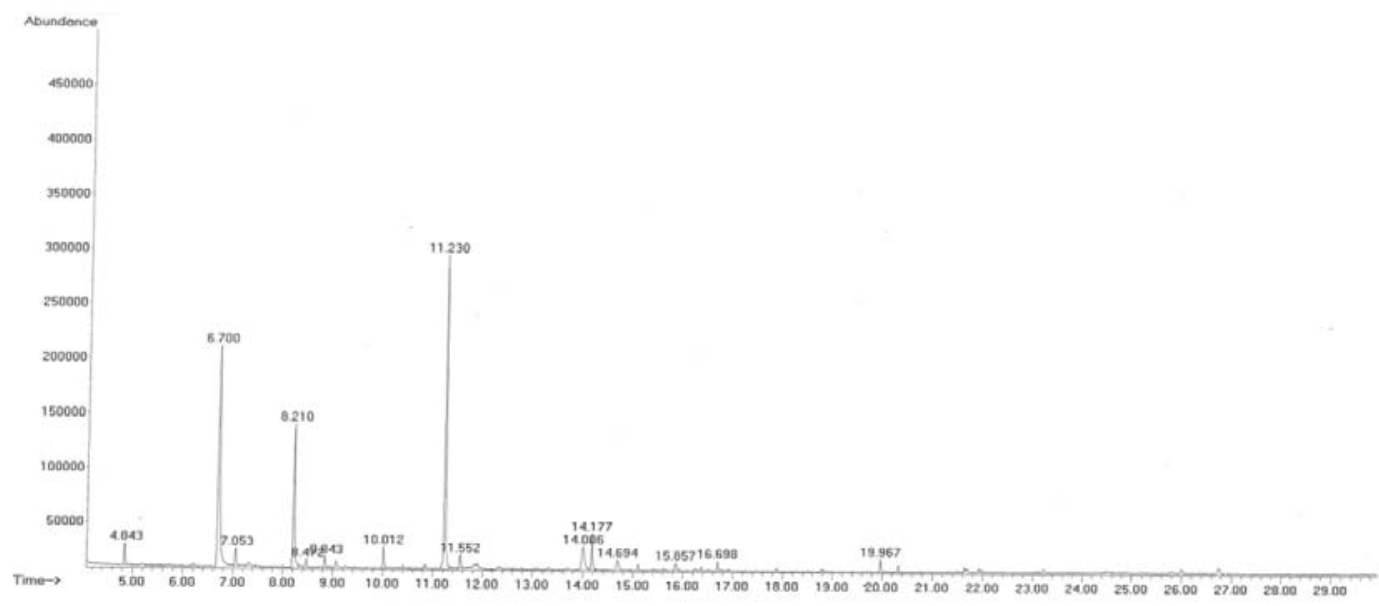

Fig. 1: GC-MS chromatogram of $T$. catappa ethanol extract

Table 3: GC-MS data of $T$. catappa ethanol extract

\begin{tabular}{lll}
\hline Peak $^{*}$ & Chemical compound & Percentage \\
\hline 4.84 & 2-Furancarboxaldehyde & 2.18 \\
6.70 & 2,5-Furandione & 31.86 \\
7.05 & 2-Furalcarboxyadehyde, 3-methyl & 1.96 \\
8.21 & Furan & 15.60 \\
8.843 & 4,5-Diamino-2-hydroxypyrimidine & 1.23 \\
10.01 & 4H-pyran-4-one & 2.24 \\
11.23 & 2-Furalcarboxyadlehyde & 29.33 \\
11.55 & 3-hydroxythiophenol 4-mercaptophenol & 1.46 \\
14.00 & Cyclophentanol & 4.51 \\
14.17 & L-Glutamic acid 5-ethyle ester & 3.49 \\
14.69 & D-allose & 1.79 \\
15.85 & Methyl. beta-d-ribofuranoside & 1.02 \\
19.96 & Hexadeconoic acid & 1.27 \\
& Total & 97.90 \\
\hline
\end{tabular}

*peak time in minutes

\section{Cyto-toxic activity of crude extracts of $T$. catappa}

Cytotoxic activity of $T$. catappa ethanol extract was carried out against COS7 and 3T3 cells at different concentrations to determine the respective $\mathrm{IC}_{50}$ by MTT assay. The results of different concentrations of T. catappa extract treatment at 0 to $1000 \mu \mathrm{g} / \mathrm{ml}$ are graphically represented in fig. 2 and 3. IC 50 values of T. catappa ethanol extract for COS7 and 3T3 were found to be $375 \mu \mathrm{g} / \mathrm{ml}$ and $750 \mu \mathrm{g} / \mathrm{ml}$, respectively. It was found that the ethanolic extract showed $0 \%$ inhibition of cell at the concentration $130 \mu \mathrm{g} / \mathrm{ml}$ and $300 \mu \mathrm{g} / \mathrm{ml}$, for COS7 and 3T3, respectively. Therefore, $130 \mu \mathrm{g} / \mathrm{ml}$ and $300 \mu \mathrm{g} / \mathrm{ml}$ concentration against COS7 and 3T3, respectively, are considered as the nontoxic concentrations. 


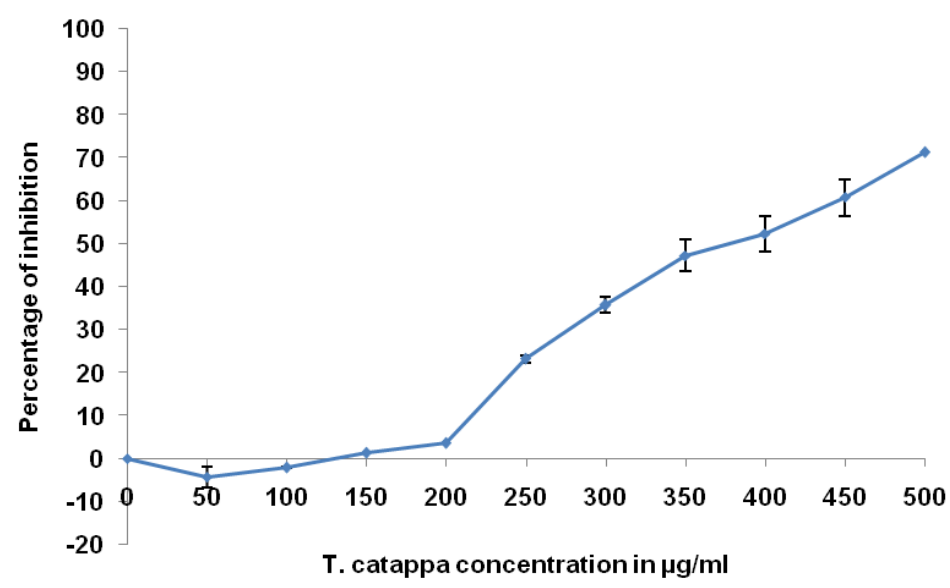

Fig. 2: Cytotoxicity of $T$. catappa crude extract against $\operatorname{CoS} 7$ cell line $(\mu \mathrm{g} / \mathrm{ml})$. Values represent the mean $\pm S D$ of the three determinants

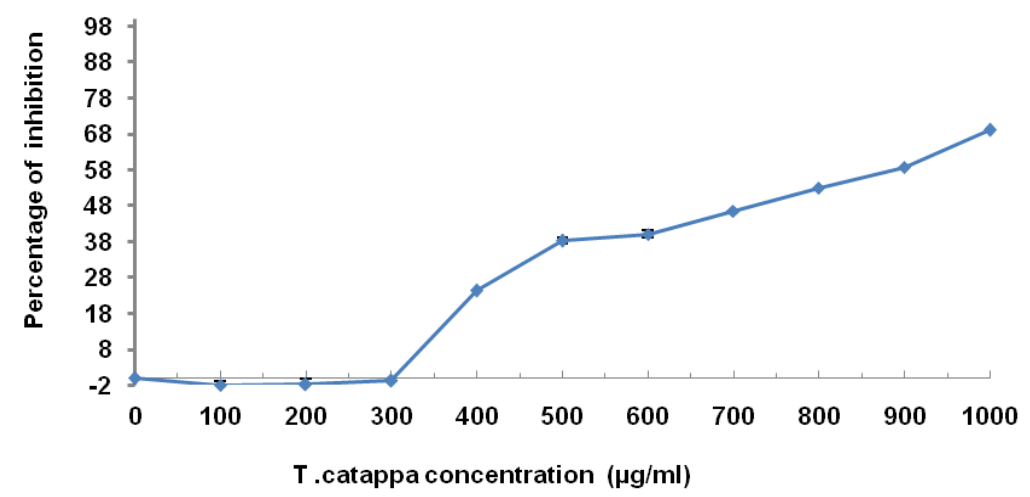

Fig. 3: Cytotoxicity of T. catappa crude extract against $3 \mathrm{~T} 3$ cell line $(\mu \mathrm{g} / \mathrm{ml})$. Values represent the mean \pm SD of the three determinants

Microscopic features of apoptosis and/or necrosis were observed adopting AO/EB staining. In this test dead cells are permeable to EB and fluoresce orange-red, whereas live cells are permeable to AO only and, therefore, fluoresce green. The viability and membrane integrity of the cells were determined based on the fluorescence pattern. The morphological changes observed in the treated cells were classified based on the fluorescence emission as follows: i) viable cells having highly organized nuclei fluoresced green; ii) early apoptotic cells which showed nuclear condensation fluoresced orange green; iii) late apoptotic cells with the chromatin highly condensed or chromatin fragmented fluoresced orange to red; and iv) necrotic cells fluoresced orange to red without chromatin fragmentation. Data on cells indicating apoptotic and necrotic morphologies (fig. 4), induced on treatment with the IC ${ }_{50}$ concentration of T. catappa for $24 \mathrm{~h}$, and collected from manual counting, are presented in fig. 5, which reveal that the $T$ catappa $\mathrm{IC}_{50}$ is highly efficient in bringing about early apoptosis but little necrosis was produced. However, 130 and 300 $\mu \mathrm{g} / \mathrm{ml}$ T. catappa (no toxicity concentration) did not induce apoptosis in both cell lines.
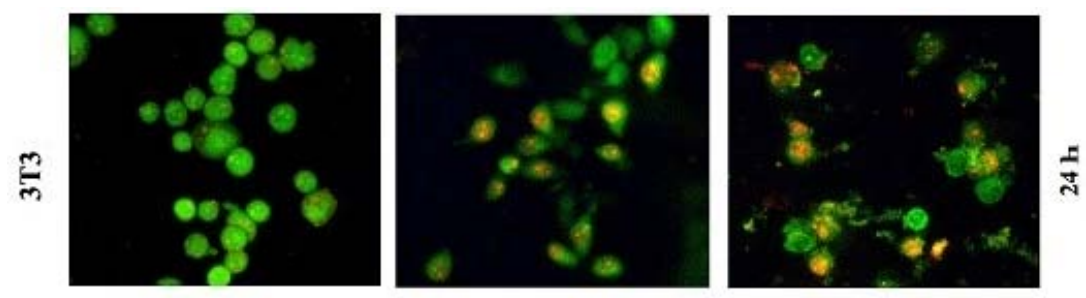

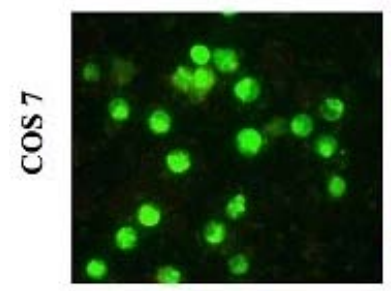

Control

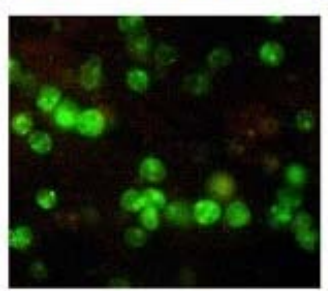

Non-toxic T. catappa

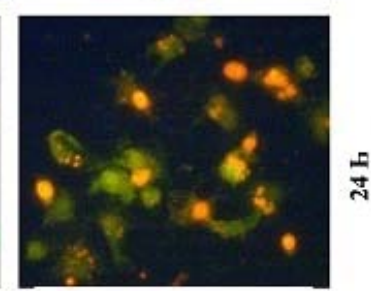

$\mathrm{IC}_{50}$ T. catappa

Fig. 4: Morphological changes observed in control and T. catappa-treated (24 h) 3T3 and COS7 cells stained with acridine orange and ethidium bromide 


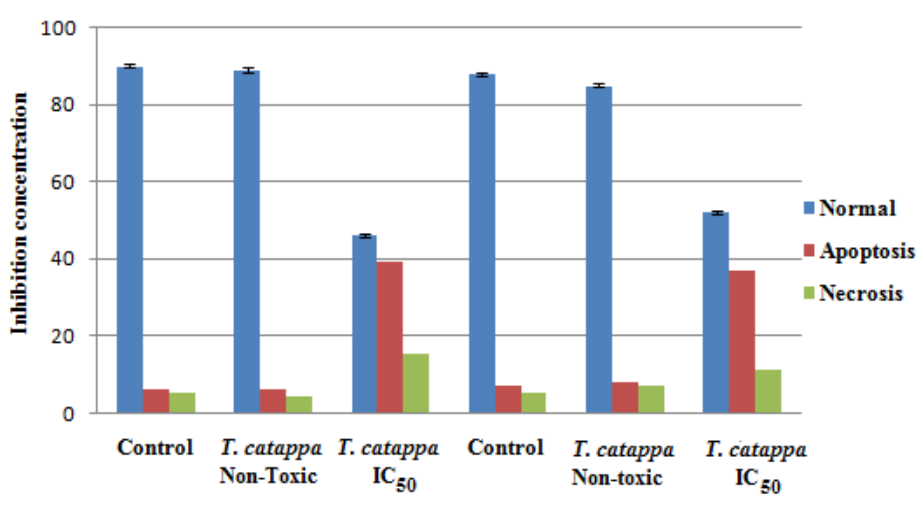

Fig. 5: Percentage of normal, apoptotic and necrotic cells. Data are expressed as mean $\pm S D$ of three independent experiments. $P<0.05$ compared to control

Hoechst 33528 staining was adopted to find the morphological changes in the nucleus as caused by treatment of IC 50 concentration and non-toxicity concentration of T. catappa (fig. 6). In control cells the nuclear chromatin was in full while after treatment with the IC 50 of $T$. catappa extract for $24 \mathrm{~h}$, changes such as chromatin marginalization, condensation and fragmentation were noticed.
These observations revealed that exposure of $T$ catappa IC $_{50}$ concentration, led to chromatin fragmentation which is a characteristic feature of apoptosis. However, treatment with no toxicity concentration indicated a fairly good percentage of normal cells. Data collected from manual counting of cells with normal and abnormal nuclear features are shown in fig. 7.
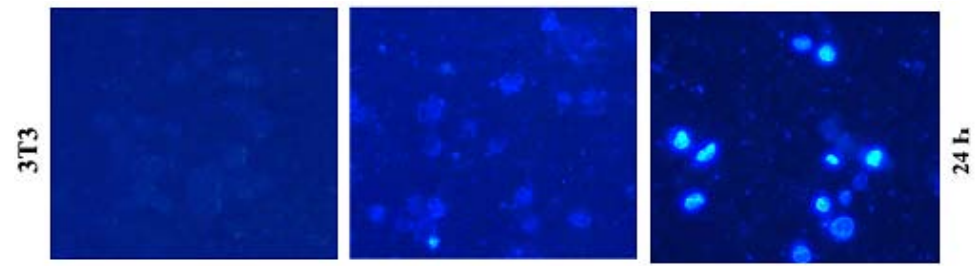

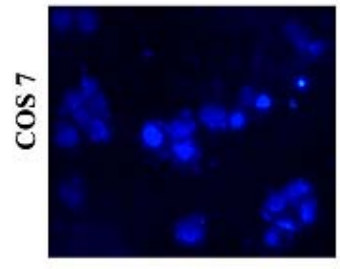

Control

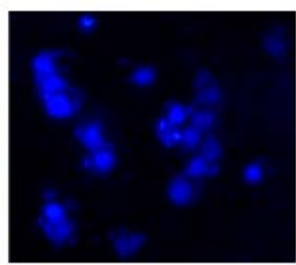

Non-toxic $T$. catappa

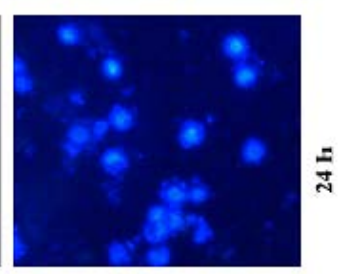

$\mathrm{IC}_{50} T$. catappa

Fig. 6: Morphological features of nuclei observed for control and extract-treated cells stained with Hoechst 33258

$3 T 3$

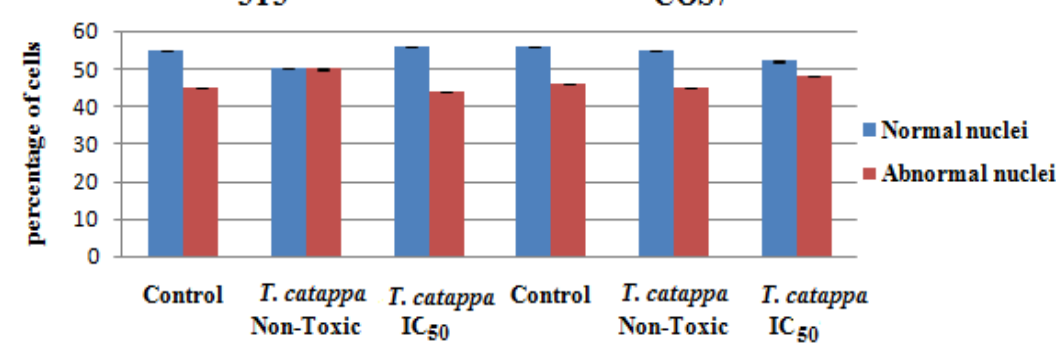

Fig. 7: Percentage of cells with normal and abnormal nuclei. Data expressed as mean \pm SD of three independent experiments. $P<0.05$ compared to control

\section{DISCUSSION}

The ethanol extract of T. catappa showed significantly higher DIZ against $S$. aureus 113 and, S. aureus ATCC 29213, respectively, than the other plants/extracts. According to Krishnaveni et al. [23] DIZ of T. catappa undiluted crude ethanol leaf extract was $7.0 \mathrm{~mm}$ against S. aureus which is a low DIZ value compared to our data. Similarly, 9 $\mathrm{mm}$ of DIZ was reported for E. coli whereas in our study it was 6.0 $\mathrm{mm}$. According to Neelavathi et al. [24] S. aureus and E. coli DIZ were 17.00 and $13.00 \mathrm{~mm}$, respectively, for $300 \mu \mathrm{g}$ extract which is comparable to our results.

Further, there has been no study for antimicrobial activity of $T$. catappa against L. monocytogenes and S. typhimurium [25]. 
T. catappa root methanol extract exhibited MIC of $0.065 \mathrm{mg} / \mathrm{ml}$ against $E$. coli and the chloroform extract exhibited MIC of $0.4 \mathrm{mg} / \mathrm{ml}$ against $S$. aureus [26]. Rajarajan et al. [27] reported that fruit pulp ethanol extract showed MIC of $0.5 \mathrm{mg} / \mathrm{ml}$ against Actinobacilus. Further, Yazdi [6] reported that T. catappa leaf methanol crude extract showed MIC of $20 \mathrm{mg} / \mathrm{ml}$ against $E$. coli whereas in our study the MIC values were $10 \mathrm{mg} / \mathrm{ml}$ and $5 \mathrm{mg} / \mathrm{ml}$ against $S$. aureus 113 and $L$. monocytogenes for $T$. catappa pericarp hexane extract. Obawemi et al. [28] reported the MIC for $S$. aureus as $1.25 \mathrm{mg} / \mathrm{ml}$ which does not agree with our data. These differences may be due to the differences in concentrations of the crude extracts, plant parts, strains and solvent type used for the extraction. Further, for $A$. purpurata ethanol extract the MIC was $<10 \mu \mathrm{g} / \mathrm{ml}$ against $S$. aureus and $1 \mathrm{mg} / \mathrm{ml}$ as MIC for E. coli [29]. It was reported that A. purpurata leaf oil extract was active against $S$. aureus strains at MIC $10 \mathrm{~g} / \mathrm{ml}$. For Gram-negatives it was more than $1000 \mathrm{~g} / \mathrm{ml}$ [30]. However, in our study the MIC was $5 \mathrm{mg} / \mathrm{ml}$ and $1 \mathrm{mg} / \mathrm{ml}$ for L. monocytogenes and E. coli, respectively.

The medicinal plant extracts used tended to precipitate once added to water-based broth media, whereas the emulsifying agent Tween 20 did not reduce the opaqueness. As a result, visual observation of the end point reading lacked precision [31-32]. Therefore, we practiced determination of MBC for each plant extract against the bacteria tested even though it was tedious. MBC values for all tested strains of $S$. aureus were found to be $80 \mathrm{mg} / \mathrm{ml}$ for T. catappa whereas for L. monocytogenes it was $20 \mathrm{mg} / \mathrm{ml}$ for A. purpurata ethanol extract. For T. catappa young leaves, the MBC was effective at $100-145 \mathrm{mg} / \mathrm{ml}$ [7].

We observed varying degrees of sensitivity of bacteria to the plant extracts tested. Generally, the trend in sensitivity was $S$. aureus $113>L$. monocytogenes $>E$. coli. This trend in sensitivity is consistent with other research findings [11] since the $S$. aureus cell wall is permeable to antimicrobial agent [33]. Further, as observed, the MIC values for these extracts were lower than the MBC values for the tested bacteria which were in agreement with other studies [7]. However, we found that $\mathrm{MBC}$ values were not always two times the MIC [11].

Abdulkadir et al. [34] showed that TPC content of T. catappa leaf methanol extract was $285.70 \mathrm{mg} \mathrm{GAE} / \mathrm{g}$ whereas for fruit extract it was $117.01 \mathrm{mg} \mathrm{GAE} / \mathrm{g}$. Marques et al. [35] reported the TPC of fruit as $142.84 \pm 2.09 \mathrm{GAE} / \mathrm{g}$. The possible explanation for these differences may be due to the differences in plant material used, since plant leaf contain more phenolic compounds than fruit pericarp, and the differences in the solvent used in extraction. Since phenol compounds are efficiently extracted in polar organic solvents than non-polar solvents, the former showed higher antibacterial activity than the hexane extract of T. catappa. Therefore, we can speculate that the strong antimicrobial activity of T. catappa is due to the phenol compounds.

GC-MS analysis of the study demonstrated that the major chemical compound of T. catappa ethanol extract was $31.86 \%$ of 2 , 5Furandione, 3 methyl. The second compound identified was 2Furalcarboxaldehyde. According to Krishnaveni et al. [36, 37], Propane 1, 1-diethoxy content was $48.58 \%$ in nut and $48.69 \%$ in stem. In contrast, Marques et al. [35] reported Z-pytol as the major compound at $42.1 \%$ in leaves and ethane 1,1-diethoxy $24.1 \%$ in bark [38]. However, no researcher has yet identified the chemical composition of fruit of T. catappa. These observations confirm that the plant part and extraction method have a great implication on the chemical compounds that would be obtained.

To find the cytotoxic effect of T. catappa fruit extract two mammalian cell lines were used. Since it is known that different cell lines might exhibit different sensitivities towards a cytotoxic compound, the use of more than one cell line is considered necessary in the detection of cytotoxic compounds [39]. Bearing this in mind, two different human cell lines were used in the present study. T. catappa showed high IC 50 value against COS7 and 3T3, 375 and $750 \mu \mathrm{g} / \mathrm{ml}$, respectively. However, so far no toxicity data has been reported in literature for T. catappa fruits. Selectivity Index (SI) calculated as SI $=$ ratio of toxicity to activity $=\mathrm{IC}_{50} / \mathrm{MIC}$. For $T$. catappa $\mathrm{SI}=300 / 10=30$ for COS7, and SI $=130 / 10=13$ for $3 \mathrm{~T} 3$. Higher SI value indicates more selectivity for bacteria and less toxicity for cells. Therefore, the ethanolic extract of $T$. catappa showed less or no toxicity to human cells.

The morphological assessments were carried out to visualize the toxicity effect of the plant extracts on particular cell lines. Less than $10 \%$ cell apoptosis was observed at $130 \mu \mathrm{g} / \mathrm{ml}$ and $300 \mu \mathrm{g} / \mathrm{ml}$ of T. catappa whereas treatment of the higher dose of $T$. catappa resulted in increase in the number of cells in apoptosis. However, the effects of these concentrations on $\mathrm{AO} / \mathrm{AB}$ were not significantly different with the control values. Therefore, the results suggest that extracts of this particular plant may not induce apoptosis at these concentrations. Further, significant difference was not observed with the normal to abnormal nuclei in control treatment with no toxicity concentration in Hoechst staining. On the other hand, NOAEC (no-observed adverse effect concentration) is defined as the concentration at which there is no cytotoxicity [40]. Therefore, NOAEC for COS7 cells was $130 \mu \mathrm{g} / \mathrm{ml}$ whereas for 3T3 it was $300 \mu \mathrm{g} / \mathrm{ml}$. However, these findings need to be confirmed using different human cell lines. Also, bioavailability of the extract needs to be evaluated in order to identify minimum/tolerant concentration of T. catappa to avoid health risks in the human/animals.

\section{CONCLUSION}

The present study aimed at identifying the antibacterial activity of the selected underutilized Sri Lankan plants against food-borne bacteria. MIC values for ethanol extracts of T. catappa and A. purpurata were $\leq$ $10 \mathrm{mg} / \mathrm{ml}$ for the tested bacteria. MBC of T. catappa was $80 \mathrm{mg} / \mathrm{ml}$ for S. aureus 113 while $20 \mathrm{mg} / \mathrm{ml}$ for L. monocytogenes V7. The major chemical compound of the ethanol extract of T. catappa was 2, 5Furandione, 3 methyl ( $31.86 \%$ ). The IC50 of T. catappa against COS7 and $3 \mathrm{~T} 3$ at were 375 and $750 \mu \mathrm{g} / \mathrm{ml}$, respectively, which are indeed very high values, much above those used in food preservation. However, the respective non-toxic concentrations of T. catappa revealed that they were not mediating apoptotic cell death. In conclusion, T. catappa pericarp is a potential source of biopreservative but additional research and clinical trials are needed for the product development to strengthen the use of T. catappa.

\section{ACKNOWLEDGEMENT}

The authors wish to thank National Research Council of Sri Lanka for the financial support (Grant No 12-054), Doerenkamp-Zbinden Foundation, Switzerland, which established the Mahatma GandhiDoerenkamp Center for Alternatives at Bharathidasan University where the cytotoxicity study was conducted, and India Science and Research Fellowship (ISRF) which provided a travel grant to Thikshani Somarathna (TS) to carry out the cytotoxicity study in India.

\section{AUTHOR CONTRIBUTION}

Experimental part of the work and writing of the manuscript were done by the first author, TS, as part of her PhD study. Dr. G. A. S. Premakumara conducted the GC-MS analysis and interpreted the data. Cytotoxicity analysis was designed and interpreted by $\mathrm{Dr}$. Mohammad A. Akbarsha; he also corrected the MS critically. Dr. Balamuthu Kadalmani executed the cytotoxicity assay and trained TS in animal cell culture. Nimsha S. Weerakkody, as the Ph. D. supervisor played crucial role in designing the study, methodology development and preliminary correction of the manuscript.

\section{CONFLICT OF INTERESTS}

Authors declare no conflict of interest

\section{REFERENCES}

1. Nascimento GGF, Locatelli J, Freitas PC, Silva GL. Antibacterial activity of plant extracts and phytochemicals on antibiotic resistant bacteria. Braz J Microbiol 2000;31:247-56.

2. Al-Mariri A, Safi M. In vitro antibacterial activity of several plant extracts and oils against some gram-negative bacteria. Iran J Med Sci 2014;39:36-43.

3. Ekor M. The growing use of herbal medicines: issues relating to adverse reactions and challenges in monitoring safety. Front Neurol 2014;4:1-10.

4. Mahesh B, Satish S. Antimicrobial activity of some important medicinal plants against plant and human pathogens. World J Agric Sci 2008;4:839-43. 
5. Anand A, Divya N, Kotti P. An updated review of Terminalia catappa. Pharmacogn Rev 2015;9:93-8.

6. Yazdi MMA. Antibacterial activity of Terminalia catappa extract against Escherichia coli isolated from urinary tract infections. Iran J Public Health 2014;43 Suppl 2:109-10.

7. Akharaiyi FC, Ilori RM, Adesida JA. Antibacterial effect of Terminalia catappa on some selected pathogenic bacteria. J Pharm Biomed Res 2011;2:64-7.

8. Nagappa AN, Thakurdesai PA, Rao N, Venkat SJ. Antidiabetic activity of Terminalia catappa Linn fruits. J Ethnopharmacol 2003;88:45-50.

9. Abiodun OO, Sood S, Osiyemi OA, Agnihotri VK, Gulati A, Ajaiyeoba EO. In vitro antimicrobial activity of crude ethanol extracts and fractions of Terminalia catappa and Vitex doniana. Afr J Med Med Sci 2015;44:21-7.

10. Ahmad I, Aqil F. In vitro efficacy of bioactive extracts of 15 medicinal plants against ES $\beta$ L-producing multidrug-resistant enteric bacteria. Microbiol Res 2007;162:264-75.

11. Kochuthressia KP, John BS, Jaseentha MO, Raj JM, Senthilkumar SR. Antimicrobial efficacy of extracts from Alpinia purpurata (Vieill.) K. Schum. against human pathogenic bacteria and fungi. Agric Biol J North Am 2010;1:1249-52.

12. Untwal LS, Kondawar MS, Chavan V. Antibacterial activity of Terminalia catappa fruit extracts. Asian J Microbiol Biotechnol Env Sci 2014;8:469-71.

13. Anusha KL, Thofeeq MD, Reddy V. In vitro studies and antibacterial activity of Alpinia purpurata. Austin J Biotechnol Bioeng 2015;2:1054-5.

14. Lobo R, Prabhu KS, Shirwaikar A, Shirwaikar A. Curcuma zedoaria Rosc. (white turmeric): a review of its chemical, pharmacological and ethnomedicinal properties. J Pharm Pharmacol 2009;61:13-21.

15. Chen Z, Wei Y, Li X, Peng C, Chenchen LZ. Antifungal activity and mechanism of major compound isolated from hexane extract of Curcuma zedoaria. Asian J Chem 2013;25:6597-600.

16. Barry AL. The antimicrobial susceptibility test: Principles and practices. Lea and Febiger, Philadelphia; 1976.

17. Hennekinne JA, De Buyser ML, Dragacci S. Staphylococcus aureus and its food poisoning toxins: Characterization and outbreak investigation. FEMS Microbiol Rev 2012;36:815-36.

18. Shan B, Cai Y-Zhong, Brooks JD, Corke $\mathrm{H}$. The in vitro antibacterial activity of dietary spice and medicinal herb extracts. Int J Food Microbiol 2007;117:112-9.

19. Mosmann T. Rapid colorimetric assay for cellular growth and survival: application to proliferation and cytotoxicity assays. J Immunol Methods 1983;65:55-63.

20. Nemati F, Dehpouri AA, Eslami B, Mahdavi V, Mirzanejad S. Cytotoxic properties of some medicinal plant extracts from Mazandaran, Iran. Iran Red Crescent Med J 2013;15:e8871.

21. Spector DL, Goldman RD, Leinwand LA. Cell: A Laboratory Manual. Culture and Biochemical Analysis of Cells. CSHL Press: Europe; 1998.

22. Latt SA, Stetten G, Juergens LA, Willard HF, Scher CD. Recent development in the detection of deoxyribonucleic acid synthesis by 33258 Hoechst fluorescence. J Histochem Cytochem 1975;23:493-505.

23. Krishnaveni M, Kumari GK, Banu CR, Kalaivani M. GC-MS/MS analysis of phytochemicals in Terminalia catappa $\mathrm{L}$ Antimicrobial assay. Indo Am J Pharm Res 2015;5:1250-4.
24. Neelavathi P, Venkatalakshmi P, Brindha P. Antibacterial activities of aqueous and ethanolic extracts of Terminalia catappa leaves and bark against some pathogenic bacteria. Int J Pharm Pharm Sci 2013;5:114-20.

25. Venkatalakshmi P, Vadivel V, Brindha P. Phytopharmacological significance of Terminalia catappa L: an updated review. Int J Res Ayurveda Pharm 2016;7:130-7.

26. Pawar SP, Pal SC. Antimicrobial activity of extracts of Terminalia catappa root. Indian J Med Sci 2002;56:276-8.

27. Rajarajan S, Asthana M, Shanthi G. In vitro bactericidal activity of lyophilized ethanolic extract of Indian almond (Terminalia catappa Linn.) fruit pulp on two pathogenic bacteria from subgingival plaques. Indian J Nat Prod Resou 2010;1:466-9.

28. Obafemi CA, Akinpelu DA, Taiwo 00, Adeloye A. Antimicrobial activity of solvent extract of Terminalia catappa Linn leaves. IFE J Sci 2006;8:29-31.

29. Santos GKN. Essential oils from Alpinia purpurata (Zingeberaceae): Chemical composition, Oviposition deterrence, larvicidal and antibacterial activity. Indian Crops Prod 2012;40:254-60.

30. Raj CA, Ragavendran P, Sophia D, Rathi MA, Gopalakrishnan VK. Evaluation of in vitro antioxidant and anticancer activity of Alpinia purpurata. Chin J Nat Med 2012;10:263-8.

31. Bazargani MM, Rohloff J. Antibiofilm activity of essential oils and plant extracts against Staphylococcus aureus and Escherichia coli biofilms. Food Control 2016;61:156-64

32. Weerakkody NS, Caffin N, Turner MS, Dykes GA. In vitro antimicrobial activity of less-utilized spice and herb extracts against selected food-borne bacteria. Food Control 2010;21:1408-14.

33. Schäffer C, Messner P. The structure of secondary cell wall polymers: How Gram-positive bacteria stick their cell walls together. Microbiology 2005;151:643-51.

34. Abdulkadir AR. In vitro antioxidant activity of ethanolic extract from Terminalia catappa (L.) leaves and fruits: Effect of fruit ripening. Int J Sci Res 2015;4:1244-9.

35. Marques MR, Paz DD, Batist LP, Rodrigues B, Celma De OA, Marcos AMM, et al. An in vitro analysis of the total phenolic content, antioxidant power, physical, physicochemical, and chemical composition of Terminalia catappa Linn fruits. Ciênc Tecnol Aliment 2012;32:209-13.

36. Krishnaveni M, Kumari GK, Kalaivani M, Banu CR. Gas chromatography-mass spectrometry/mass spectrometry analysis of Terminalia catappa L. Nut and antimicrobial assay. Asian J Pharm Clin Res 2015;8:168-70.

37. Krishnaveni M, Kumari GK, Banu CR, Kalaivani M Phytochemical analysis of Terminalia catappa stem using GCMS/MS. Res J Pharm Technol 2015;8:1281-3.

38. Venkatalakshmi P, Brindha P, Saralla RP. Analytical and chemical standardisation studies on Terminalia catappa bark. Int J Pharm Pharm Sci 2014;6(Suppl 1):4-8.

39. Surekha RD, Shankar NB. Cytotoxicity of stem extracts of selected cassia species against He La and breast cancer cell lines in vitro. Asian J Pharm Clin Res 2017;10:80-2.

40. Food and Agriculture Organization (FAO) and World Halth Organization (WHO). In: Principles and Methods for the Risk Assessment of Chemicals in Food. Risk Characterization; 2009. p. 1-18. 